\title{
Justice in Wales for the People of Wales
}

\author{
Nason, Sarah
}

\section{Edinburgh Law Review}

DOI:

https://doi.org/10.3366/elr.2020.0636

Published: 01/05/2020

Peer reviewed version

Cyswllt i'r cyhoeddiad / Link to publication

Dyfyniad o'r fersiwn a gyhoeddwyd / Citation for published version (APA):

Nason, S. (2020). Justice in Wales for the People of Wales. Edinburgh Law Review, 24(2), 297304. https://doi.org/10.3366/elr.2020.0636

\footnotetext{
Hawliau Cyffredinol / General rights

Copyright and moral rights for the publications made accessible in the public portal are retained by the authors and/or other copyright owners and it is a condition of accessing publications that users recognise and abide by the legal requirements associated with these rights.

- Users may download and print one copy of any publication from the public portal for the purpose of private study or research.

- You may not further distribute the material or use it for any profit-making activity or commercial gain

- You may freely distribute the URL identifying the publication in the public portal ?
}

Take down policy

If you believe that this document breaches copyright please contact us providing details, and we will remove access to the work immediately and investigate your claim. 


\section{Justice in Wales for the People of Wales}

In October 2019 the Commission on Justice in Wales published its Report, Justice in Wales for the People of Wales. ${ }^{1}$ Established by former First Minister, Carwyn Jones AM, it commenced work in December 2017 and was chaired by former Lord Chief Justice of England and Wales, Lord Thomas of Cwmgiedd.

The Commission's 555-page Report includes 78 numbered recommendations and approximately 150 total recommendations. It was guided not by questions about jurisdictional arrangements, but by the principle that justice is at the heart of any system of democratic governance. Nevertheless, the Commission states that its unanimous finding, that people in Wales are being let down by the current system, ${ }^{2}$ can only be remedied by full legislative and executive devolution of responsibility for justice. ${ }^{3}$

The Report contains 12 Chapters, including historical context and guiding principles; Information, advice and assistance; Criminal justice; Family justice; Civil justice; Administrative justice and coroners; Delivering justice; The legal sector and economy of Wales; Knowledge, skills and innovation; Welsh language; and Governance, the law of Wales and the judiciary.

The UK Ministry of Justice's response, by tweet within 15mins of the Report's publication, was to reiterate its belief that a single legal jurisdiction remains the most effective way to deliver justice across England and Wales. In a Westminster Hall debate, moved by Liz Saville-Roberts MP Plaid Cymru, Parliamentary Under-Secretary of State for Justice Chris Philp MP stated that there will be no formal UK Government response to the Report. ${ }^{4}$ The UK Government intends to continue discussions with Welsh Government, and honour commitments made during the passage of the Wales Act 2017 to undertake regular reviews of justice in Wales. Mr Philp MP argued that the costs of devolving justice would be disproportionate given the comparative volume of devolved and reserved legislation. Political discussion to date has focused on the Commission's recommendations on devolution of criminal justice and prisons, family justice, and legal aid. ${ }^{5}$ However, it is recognised that improvements could be made to administrative justice, where Wales already has devolved responsibilities, providing a 'test bed' for devolution of additional powers. ${ }^{6}$

\section{A. GOVERNANCE, THE LAW OF WALES AND THE JUDICIARY}

The justice system in Wales is complex and fragmented and the Commission concluded that the existing devolution settlement provides little opportunity to develop a coherent approach and targeted use of resources. ${ }^{7}$ It drew on research evidence ${ }^{8}$ that in $2017 / 18$ almost $£ 1,165$ million was spent on the justice system for Wales, equating to approx. $£ 370$ per person in Wales, and around $3.6 \%$ of total identifiable public spending for Wales, but that almost $40 \%$ of this expenditure is already contributed through the Welsh budget and taxation. Justice in Wales has been consistently underfunded from Westminster, with revenue expenditure on court

\footnotetext{
${ }^{1}$ Online at: https://gov.wales/sites/default/files/publications/2019-

10/Justice\%20Commission\%20ENG\%20DIGITAL_2.pdf (the 'Commission')

2 'Commission' Executive Summary, para 1.

3 'Commission' Recommendations 58 and 59.

${ }^{4}$ Commission on Justice in Wales, Hansard 22 January 2020 Vol 670, cols138WH-160WH.

${ }^{5}$ See e.g., Plenary session of the National Assembly for Wales 4 February 2020, online at: https://record.assembly.wales/Plenary/6079\#A56125

${ }^{6}$ S Nason, Administrative Justice, Wales' First Devolved Justice System: Evaluation and Recommendations

(Bangor/ESRC IAA 2018).

7 'Commission' para 12.11 .

${ }^{8}$ G Ifan, Fiscal Implications of Devolving Justice (Wales Governance Centre, Cardiff University 2019).
} 
and tribunal services and legal aid being below what would be its population share. As such the Commission recommends: "Devolution of justice must be accompanied by a full transfer of financial resources, including all identifiable administrative and capital resources relating to Wales". ${ }^{9}$ Full devolution is necessary to enable the proper alignment of justice policy and spending with devolved policies in education, health and economic development; to place justice at the heart of government; and to take advantage of Wales' size and ability to innovate. The Commission also stated that further devolution could strengthen the UK constitution. ${ }^{10}$

In relation to the judiciary, the Commission recommends that future legislation should provide for the Assembly to establish a Welsh High Court and Court of Appeal. ${ }^{11}$ Under the current scheme of devolution, it recommends changes in organisation of the senior judiciary to improve leadership and provide for more effective relationships with the political branch, and that Wales should be put in a similar position to Scotland and Northern Ireland regarding the appointment of judges to the Supreme Court. ${ }^{12}$

Accountability depends on people knowing who is responsible for justice policy and justice delivery. Whilst this remains complex, the National Assembly has voted to change the name and remit of its Constitutional and Legislative Affairs Committee; to the Legislation, Justice and Constitution Committee, which is beginning to formally scrutinise justice for the first time in the Assembly's history. ${ }^{13}$ A Cabinet sub-committee on Justice has been established, comprising the First Minister, the Counsel General for Wales, and the Deputy Minister and Chief Whip. A Justice Commission implementation team has been created within Welsh Government.

\section{B. CRIMINAL AND FAMILY JUSTICE}

Criminal justice and family justice provide strong, sometimes heart-wrenching, evidence of the difficulties caused by the division of responsibilities between Westminster and Cardiff. In criminal justice the lack of alignment between policy and spending is said to severely impact the ability of the criminal justice system to be effective in reducing crime and promoting rehabilitation. Too little attention is paid to the treatment of victims, mental health issues are not properly addressed, a significantly greater proportion of spending is on prisons rather than crime reduction, and Wales has one of the highest prison populations per head in Europe. ${ }^{14}$ There is a lack of facilities for women offenders, BAME people are over-represented, and the current devolution settlement causes problems for providing health services to prisoners, and other services on release including housing. UK Government plans for additional prison places could also result in Wales becoming a net importer of prisoners from England. The Commission makes 16 relevant recommendations, including the devolution of youth justice policy, an integrated whole-system approach to offender management, establishing problemsolving courts, and that policing and crime reduction policy, including drug abuse and mental health issues, be determined in Wales. ${ }^{15}$

After finding that there has been an unsustainably high increase in the number of children being taken into care in Wales, the Commission recommends vigorous support for a

\footnotetext{
9 'Commission' Recommendation 60.

10 'Commission' Chapter 12.

11 'Commission' Recommendation 75.

12 'Commission' Recommendation 67.

${ }^{13} \mathrm{https}: / / \mathrm{www}$.assembly.wales/en/newhome/pages/newsitem.aspx ?itemid=2070

${ }^{14}$ R Jones, Sentencing and Immediate Custody in Wales: A Factfile (Wales Governance Centre, Cardiff University 2019).

15 'Commission' Chapter 4.
} 
programme of research to underpin reform of Welsh family justice and associated preventative services. ${ }^{16}$

Matters of criminal and family justice have been subject to the lengthiest contributions in political debate and require more thorough examination than can be achieved here.

\section{THE LEGAL SECTOR AND ECNOMY, KNOWLEDGE, SKILLS, INNOVATION AND THE WELSH LANGUAGE}

The Commission proposes a strategy to reinvigorate the rural and post-industrial legal sector and recommends that Welsh Government provides leadership, including support for investment in technology. It recommends continuance of the system where legal practitioners can practise in England and Wales, and where the legal professions are jointly regulated, ${ }^{17}$ to the benefit of the legal economy in Wales.

Welsh law schools are tasked to reassess their undergraduate programmes, ensuring that devolved law is taught as part of the undergraduate syllabus, whilst maintaining opportunities for comparative law studies and transferable qualifications rendering Welsh degrees attractive to students from across the UK and internationally. ${ }^{18}$ This challenge for Welsh law schools is in addition to broader curriculum reforms that may necessarily have to be introduced in most institutions as a result of the impending Solicitors Qualifying Examination (SQE). The Commission also recommends that professional legal education for those wishing to practise in Wales must be available in the Welsh language, with phased introduction of the availability of all professional examinations in Welsh. At the time of writing the Solicitors Regulation Authority is yet to commit to providing SQE examination papers in Welsh, though it has proposed that students might be able to write their answers in Welsh. Welsh law schools, including Bangor University which delivers a large volume of teaching and assessment through the medium of Welsh, have been providing ongoing evidence to the SRA that its concerns over the costs of translation, and ensuring equivalence between English and Welsh tests, are unfounded. The Commission also recommends that all justice bodies be subject to the Welsh Language (Wales) Measure 2011. ${ }^{19}$

The Commission addresses the lack of data available on a disaggregated Wales-only basis about a range of matters relating to the justice system. Some relevant data is not currently kept, e.g., the caseload of the courts in Wales and England in relation to types of Welsh law applications. The Commission recommends that "specific data should be collected and published on a sufficient scale to enable disaggregation, with a view to proper evidence-based policy development and as a basis for research". ${ }^{20}$

\section{ADVICE, INFORMATION AND ASSISTANCE}

Much evidence to the Commission demonstrated the disproportionate impacts cuts to legal aid have had in Wales compared to England, resulting in 'advice deserts'; serious risks to the sustainability of legal practice; and increases in the number of people representing themselves. ${ }^{21}$ The Commission concluded that determination and delivery of legal aid policy in Wales would facilitate overall coordination of the provision of legal aid and advice services

\footnotetext{
16 'Commission' Chapter 5.

17 'Commission' Recommendation 74.

18 'Commission' Recommendations 46 and 48.

19 'Commission’ Recommendation 52.

20 'Commission' Recommendation 50.

21 'Commission' Chapter 3 and evidence on the Commission's website: https:/gov.wales/commission-justicewales
} 
to meet people's needs. It recommends that "funding for legal aid and for the third sector providing advice and assistance should be brought together in Wales to form a single fund under the strategic direction of an independent body".22

Welsh politicians have stressed that making rights a reality was a pillar of the welfare state; it being no coincidence that legal aid was introduced in 1949 covering the overwhelming majority of the population. ${ }^{23}$ In response to the 2014 Low Commission Report on the Future of Advice and Legal Support in England and Wales, Welsh Government established a National Advice Network to develop and support delivery of a strategic approach to the provision of social welfare advice services. For some, combining this with the Commission's recommendations, may lead to a nascent national legal service for Wales. However, the advice sector responds to a variety of need profiles, and the fund would have to be flexibly allocated, administered and overseen. Strategic direction should be independent from the third sector to a degree (which is already perceived by some as too close to Government). The composition and expertise of the directing body will be crucial, alongside its reporting duties to Government and the Assembly.

\section{E. CIVIL AND ADMINISTRATIVE JUSTICE}

Refreshingly, the Commission recognised: "Administrative justice is the part of the justice system most likely to impact upon the lives of people in Wales". ${ }^{24}$ It also stressed that: "Whatever the current state of divergence [between Welsh and English law], it seems safe to conclude that it is in the field of substantive administrative law that the scope for divergence has the most potential in the short term". ${ }^{25}$ Wales has also developed 'general administrative laws' designed to promote and protect human rights, principles and values (including the rights of children, older people and disabled people, the rights of future generations through principles of sustainability and well-being, and Welsh-specific equality duties). ${ }^{26}$ The Commission suggests that innovations in Welsh administrative law support its recommendation that: "The law applicable in Wales should be formally identified as the law of Wales, distinct from the law of England". ${ }^{27}$ The Commission recognises that:

Wales has far sighted policies on future generations, sustainability, and international standards on human rights. These are, however, not integrated with the justice system. The distinctive legal framework being developed to underpin these policies, including the creation of independent public officers whose role is to promote and protect rights, is not aligned to the justice system. ${ }^{28}$

The Commission gives as an example the Well-being of Future Generations (Wales) Act 2015, which places the sustainable development principle at the heart of public administration, but which does not provide for legally enforceable routes to redress in the courts or tribunals for breach of that principle. This is to be compared with the UK Future Generations Bill which provides for specific judicial remedies akin to sections 6 and 8 of the Human Rights Act 1998. That many duties under general Welsh administrative procedure law operate at a strategic or policy level rather than being directly enforceable through courts or tribunals, appears to be a

\footnotetext{
22 'Commission' Recommendation 1.

${ }^{23}$ See 'Assembly Plenary' (n 5) and 'Westminster Hall' (n 4).

24 'Commission' para 6.1.

25 'Commission' para 6.15.

${ }^{26}$ S Nason, 'The "New Administrative Law” of Wales' (2019) PL 703.

27 'Commission' Recommendation 73.

28 'Commission' para 12.21.
} 
political choice. The broader question is whether this is at least partially attributable to lack of practical control over court architecture. There has, for example, been delayed implementation of substantive Welsh administrative law provisions due to the difficulties of developing Civil Procedure Rules within HMCTS England and Wales. Nevertheless, the creation of 'independent public officers' (such as Commissioners) to promote rights, rather than courtbased enforcement (excepting occasional resort to the 'back-stop' of judicial review), may be as much due to Welsh approaches to collective rather than individualised justice, evident in areas of policy-making including homelessness, as it is to lack of responsibility for the administration of courts. After his tenure as Chair of the Commission, Lord Thomas was critical of aspirational legislation, including the Welsh Future Generations legislation, as raising false hopes and undermining the rule of law. ${ }^{29}$ His central interrelated conclusions were: first, that legislation which seeks to improve administrative decision-making must be drafted with sufficient precision to enable an appropriate court, tribunal or other enforcement body to determine whether relevant duties have been discharged on the basis of objective evidence; second, that the use of different enforcement mechanisms should be explored which could include a court or tribunal, but also potentially an ombud with an adjudicative role, or a commissioner with enforcement powers (beyond those of the Future Generations Commissioner for Wales, which have been described as name and shame powers). Even in administrative law which is significantly devolved, and where rights-promotion and equality are sought to be mainstreamed as policy objectives, the historic lack of competence over justice, and corresponding resource concerns, may have limited capacity for enforcement, and led to mirroring inefficient England and Wales approaches to dispute resolution. The Commission concludes that the 'ad hoc' England and Wales approach should not be maintained:

The processes of the court and tribunal system are not easy to understand without advice. Many courts and tribunals have come about in part as a matter of history and in part out of a desire to provide simpler and cheaper means of dispute resolution... The system has never been rationalized, it is unduly complex and it should be better aligned with legal aid...Our analysis is that the current structure for resolving disputes demonstrates that there is a need to unify courts and tribunals, both for civil justice and administrative justice. ${ }^{30}$

In the longer-term, and with legislative devolution, the Commission recommends "a Welsh Courts and Tribunals Service should be developed from the base of a Welsh Tribunals Unit reformed on the model of the Scottish Courts and Tribunals Service". ${ }^{31}$ Noting that: "The current system of challenging public bodies in Wales is complex", the Commission concludes: "As a short term measure there is a need for better coordination in relation to administrative justice so that the public have a clear understanding on where to go to have their disputes resolved". ${ }^{32}$ As such it recommends: "Dispute resolution before courts, tribunals, alternative dispute resolution and ombudsmen, as well as dispute resolution in respect of administrative law, should be promoted and coordinated in Wales through a body chaired by a senior judge". ${ }^{33}$ And further: "All public bodies, ombudsmen and other tribunals which have been established

\footnotetext{
${ }^{29}$ Lord Thomas, 'Thinking policy through before legislating - aspirational legislation' (Statute Law Society, Renton Lecture 2019).: http://www.statutelawsociety.co.uk/home/lord-thomas-text-aspirational-legislation-2111-19/

30 'Commission' para 5.56.

31 'Commission' Recommendation 76.

32 'Commission' para 6.60.

33 'Commission' Recommendation 21.
} 
under Welsh law or by the Welsh Government, which make judicial or quasi-judicial decisions, and are not currently subject to the supervision of the President of Welsh tribunals, should be brought under the supervision of the President". ${ }^{34}$ This is a broader role than anticipated when the President of Welsh Tribunals was created under the Wales Act 2017. The Commission also recommends: "The Welsh Tribunals Unit should have structural independence which it currently lacks, and be placed under judicial control". ${ }^{35}$ More extensive judicial control should not, however, be achieved at the expense of flexibility that has been an asset across the Welsh tribunals and ombuds landscape. The Law Commission is currently examining the devolved Welsh tribunals, including their independence, procedures and regulations, appointments processes, and onward appeal routes. This will draw on the experience of ongoing tribunal reforms in Scotland, including delays to that process.

The Commission also recognised the extent to which public administrative law disputes against devolved Welsh authorities have continued to be determined in England. One reason for this it said, "has been a tendency in the legislation passed by the Assembly for it to specify that dispute resolution should take place in the County Court or in the non-devolved courts and tribunals". ${ }^{36}$ Whilst noting that the devolved Welsh tribunal judiciary is small and adds to the fragmented structure of justice in Wales, the Commission concludes that the minimal use of devolved Welsh tribunals is anomalous given their specialist competence and capacity. It also recommends greater transparency about the level and distribution of expenditure on external legal services by Welsh Government, local authorities and other public bodies; past research having disclosed instances of large-scale instruction of lawyers based in England, including in claims turning on Welsh law. ${ }^{37}$ The Commission recommends "that it should be compulsory under the Civil Procedure Rules for cases against Welsh public bodies which challenge the lawfulness of their decisions to be issued and heard in Wales" 38 and that: "The Welsh tribunals should be used for dispute resolution relating to future Welsh legislation". ${ }^{39}$ Implementation of this latter recommendation would have impacts on dispute resolution mechanisms in legislation currently passing through the Assembly, as well as on much future legislation.

The Commission also recommends implementation of England and Wales Law Commission proposals from 2011 on Public Services Ombudsmen, ${ }^{40}$ namely that the Administrative Court in Wales should have a specific power to stay proceedings for the Public Services Ombudsman for Wales (PSOW) to investigate, and the PSOW should have a power to refer a point of law the courts. ${ }^{41}$ These recommendations will require engagement with the UK Ministry of Justice, and changes to Civil Procedure Rules, if not also primary legislation. Some two-thirds of the Commission's recommendations require at least some engagement with the UK Ministry of Justice, but as discussed above, there are many in administrative justice which can be progressed immediately. Including, for example, the Commission's view that an examination of the case for a housing court/tribunal for Wales is overdue given the devolution of housing policy, ${ }^{42}$ and that there should be an appraisal of school admissions and exclusions

\footnotetext{
34 'Commission' Recommendation 25.

35 'Commission' para 6.59.1 and Recommendation 27.

36 'Commission' para 6.59.2.

${ }^{37}$ Public Law Project and S Nason, Evidence to the Commission on Justice in Wales: https://llyw.cymru/sites/default/files/publications/2018-11/submission-to-the-justice-commission-from-publiclaw-project-sarah-nason.pdf

38 'Commission' Recommendation 24.

39 'Commission' Recommendation 27.

${ }^{40}$ Law Commission, The Public Services Ombudsmen (Law Com No.329, 2011).

41 'Commission' Recommendation 26.

42 'Commission' para 5.35.
} 
appeal panels which it considers operate without any kind of judicial scrutiny. ${ }^{43}$ In each of these examples, and in others, Wales can both learn from, and teach, other devolved nations.

43 'Commission' para 6.47 